\title{
Sistem Informasi Penjualan pada Toko Besi dan Bangunan Subur Delanggu
}

\author{
Budhi Sumboro $^{1}$, Anton Respati Pamungkas ${ }^{2}$, Radova Sekar Jagad ${ }^{3}$ \\ ${ }^{123}$ Program Studi Sistem Informasi, STMIK AUB, Surakarta, Indonesia \\ e-mail: *1 budhi.sumboro@stmik-aub.ac.id, ${ }^{2}$ anton18@stmik-aub.ac.id, ${ }^{3}$ radovasj@gmail.com
}

\begin{abstract}
Abstrak
Subur adalah toko besi dan bahan bangunan yang menjual bermacam-macam jenis bahan bangunan dengan sebagian besar pelanggan dari kalangan pemborong atau kontraktor dengan melakukan pembayaran secara termin. Saat menjalankan kegiatan usaha sehariharinya masih menggunakan cara konvensional seperti kalkulator, transaksi penjualan masih dilakukan secara tertulis sehingga sering terjadi ketidakcocokan antara data barang yang dibeli dengan barang yang tersedia serta dibutuhkan waktu yang lama dalam proses pembuatan laporan penjualan. Tujuan penelitian ini merancang program sistem informasi penjualan yang dapat memudahkan dalam mengontrol persediaan (inventory) agar akurasi informasi laporan terjamin serta mengefektifkan tingkat waktu pelayanan dan mengurangi tingkat kesalahan yang dilakukan oleh manusia pada Toko Besi dan Bangunan Subur. Oleh karena itu perlu membuat sistem informasi penjualan yang baik dan berguna. Metode pengumpulan data yang digunakan adalah observasi, wawancara, dan studi pustaka. Metode penulisan yang digunakan adalah deskripsi dan eksposisi. Metode pengembangan sistem informasi meliputi perencanaan, analisis, desain, dan implementasi. Pembuatan aplikasi sistem penjualan dengan menggunakan Microsoft Visual Basic 6.0, penyimpanan dengan menggunakan MySQL. Hasil dari penyusunan penelitian ini berupa pengolaha data barang, data pelanggan, data pemasok, transaksi pembelian, transaksi penjualan, transaksi retur barang, transaksi pembayaran hutang dan laporan-laporan transaksi penjualan dan pembelian secara berkala. Kesimpulan sistem informasi penjualan terkomputerisasi yang dapat menghasilkan laporan transaksi penjualan yang lebih cepat, tepat, efektif, dan akurat pada Toko Besi dan Bangunan "Subur" Delanggu.
\end{abstract}

Kata kunci: Sistem, Informasi, Penjualan

\section{PENDAHULUAN}

Sistem penjualan dan pembelian merupakan bagian yang penting dalam pengoperasian suatu perusahaan atau usaha, baik perusahaan manufaktur maupun perusahaan dagang. Pembuatan atau pengaturan sistem penjualan berpengaruh pada tingkat penerimaan pendapatan perusahaan, sedangkan sistem pembelian memberikan pengaruh pada informasi penerimaan barang yang diperoleh dari pemasok. Oleh karena itu perusahaan harus benar-benar mengawasi dan mengendalikan kegiatan penjualan serta pembelian dengan menerapkan sistem yang memadai, sehingga target penjualan dapat dicapai.

Sebuah sistem informasi yang baik sangat diperlukan dalam membantu kegiatan operasional suatu perusahaan agar berjalan maksimal. Penggunaan sistem informasi ini biasanya ditujukan pada kegiatan utama dalam perusahaan, yaitu siklus penjualan dan penagihan piutang kepada pelanggan. Hal ini disebabkan karena penjualan merupakan sumber pendapatan utama bagi perusahaan. Sedangkan piutang usaha yang terlambat dibayarkan akan menyebabkan kegiatan operasional perusahaan terganggu dan dapat mempengaruhi keputusan yang akan

Received November 11, 2019; Revised November 25, 2019; Accepted December 9, 2019 
diambil manajemen perusahaan dalam jangka waktu ke depan. Oleh karena itu, pemberian piutang kepada pelanggan harus dilakukan dengan tepat sesuai dengan kondisi masing-masing pelanggan agar kegiatan operasional perusahaan dapat berjalan dengan lancar. Pembayaran piutang yang terlambat dapat berdampak pada dana kas yang menurun. Selain itu, dapat menyebabkan juga pembayaran hutang kepada pemasok bahan baku menjadi terlambat. Lama kelamaan pemasok akan enggan mengirimkan bahan bakunya. Hal ini dapat menyebabkan kegiatan operasional perusahaan juga akan terganggu.

Toko Subur adalah toko besi dan bahan bangunan yang menjual bermacam-macam jenis bahan bangunan seperti semen, besi, cat, kayu, paku, baja ringan, perlengkapan rumah dan jenis lainnya. Pelanggan banyak dari kalangan pemborong atau kontraktor yang sering membeli dengan jumlah banyak dan melakukan pembayaran dengan cara termin sesuai jatuh tempo yang telah disepakati. Pembelian barang dilakukan dengan cara memesan ke pemasok yang banyak berasal dari luar kota. Pembayaran untuk pembelian barang dilakukan dengan cara termin dengan jatuh tempo yang telah ditentukan. Transaksi penjualan dan informasi persediaan serta pengelolaan hutang piutang menjadi masalah utama dalam mengelola toko besi dan bangunan Subur. Selain permasalahan tersebut, pemilik toko menginginkan rekap pembelian oleh pelanggan dalam satu tahun. Rekap tersebut digunakan untuk menentukan nominal, barang yang akan diberikan kepada pelanggan menjelang hari raya idul fitri.

Saat menjalankan kegiatan usaha sehari-harinya masih menggunakan cara konvensional antara lain proses transaksi penjualan membutuhkan waktu yang cukup lama karena masih menggunakan alat bantu seperti kalkulator serta pencatatan transaksi penjualan masih dilakukan secara tertulis, sering terjadi ketidakcocokan antara data barang yang dibeli dengan barang yang tersedia sehingga mempersulit dalam proses pencarian barang dan pengolahan data barang maupun pembuatan laporan persediaan barang, dibutuhkan waktu yang cukup lama dalam proses pembuatan laporan penjualan, laporan pembelian serta laporan persediaan barang dikarenakan sering melakukan pengecekan ulang barang dalam membuat laporan tersebut sedangkan pemilik membutuhkan laporan secepatnya. Oleh karena itu proses yang berjalan di Toko Besi dan Bangunan Subur mempunyai kelemahan tersendiri, dari segi kecepatan, keakuratan, pendokumentasian yang sangat minim karena tidak mempunyai sistem yang jelas terhadap pengelolaan transaksi penjualan.

Dampak dari sistem yang berjalan akan penulis analisis untuk membuat sistem baru yang dapat membantu meningkatkan kecepatan dari segi penerimaan data dan informasi yang lebih baik, keakuratan dari segi pengelolaan data dan informasi yang diperlukan, serta pendokumentasian yang lebih baik dari sebelumnya. Solusi yang ditawarkan dalam penelitian ini adalah dibuatnya sistem yang dapat mengelola data dan transaksi dengan baik. Sistem yang dibuat harus dapat menangani permasalahan yang terjadi, terutama jenis transaksi yang banyak dan dapat menghasilkan informasi atau laporan yang dibutuhkan pemilik. Pencarian data, validasi data dan otomatisasi juga akan menjadi fokus dalam sistem yang dibuat sehingga dapat meminimalisasi kesalahan yang berasal dari pengguna. Informasi persediaan barang dan berbagai laporan yang dibutuhkan merupakan salah satu hasil dari sistem yang dibuat sehingga pemilik atau pengguna dapat mengetahui informasi yang dibutuhkan dengan cepat.

Dalam pengembangan sistemnya, akan digunakan konsep POS (point of sales) yang dapat membantu lingkup pengembangan sistemnya yaitu di dalam transaksi penjualan dan semua transaksi yang ada di dalamnya sehingga tidak hanya meliputi transaksi penjualan saja, tetapi menyangkut pengelolaan transaksi pembayaran dan penyusunan laporan.

Berdasarkan latar belakang penelitian diatas, maka perlu diciptakan suatu sistem informasi untuk melakukan pencatatan barang dari supplier, perhitungan stok barang, kapan harus melakukan permintaan untuk pengadaan barang, sampai pada pembuatan report penjualan dan pembelian menggunakan sistem aplikasi database sehingga dalam perhitungan stok barang, dan dalam penyimpanan datanya akan menggunakan satu database yang terintegrasi. Maka judul yang akan diambil untuk penulisan penelitian ini adalah "Sistem Informasi Penjualan Toko Besi dan Bangunan Subur Delanggu". 


\section{METODE PENELITIAN}

\subsection{Metode Penelitian}

2.1.1 Objek Penelitian

Penelitian ini dilakukan di Toko Besi Dan Bangunan Subur yang beralamat di Jalan Raya

Klaten-Solo Km. 24, Delanggu, Klaten.

2.1.2 Alat Dan Sumber

Alat yang digunakan dalam proses pembuatan penelitian ini adalah sebagai berikut :

1) Perangkat keras berupa 1 unit laptop dengan spesifikasi Intel Core 2 Duo.

2) Perangkat lunak berupa Windows 7, Visual Basic Versi 6.0, MySQL dan Microsoft Office 2007.

Sumber penelitian yang digunakan untuk penelitian adalah :

1) Data yang ada di toko besi dan bangunan Subur berupa data barang, data pelanggan dan data pemasok.

2) Nota penjualan baik tunai maupun termin, dan prosedur pembayaran hutang.

3) Jenis dan bentuk laporan pembukuan manual.

\subsubsection{Teknik Pengumpulan Data}

Pada tahap ini dilakukan pengumpulan data dan fakta, dalam pengumpulan data dan fakta ini menggunakan teknik pengumpulan data sebagai berikut .

1) Observasi

Peneliti melakukan observasi dibagian penjualan dan mengamati sistem informasi penjualan yang sedang berjalan.

2) Wawancara

Wawancara dilakukan dengan pemilik toko yang berhubungan langsung dengan sistem informasi penjualan yang sedang berjalan.

3) Studi Literatur

Metode pengumpulan data dengan mempelajari sumber-sumber buku yang berkaitan dirangkum sebagai acuan penulisan

\subsubsection{Tahapan Penelitian}

Kegiatan penelitian ini dalam bentuk pengembangan perangkat lunak dan menggunakan

Waterfall Model, tahapan-tahapan pengembangan yang dilakukan adalah Requirement analysis and definition, system and software design, implementation and unit testing, integration and system testing, dan operation and maintenance. Tahapan-tahapan tersebut saling terkait dan saling mempengaruhi membentuk sebuah siklus hidup perangkat lunak (Software Development Life Cycle).

Langkah-langkah yang akan ditempuh dalam penelitian ini adalah:

1) Requirements analysis and definition

Tahapan ini merupakan proses dimana peneliti menentukan klasifikasi data yang akan membantu dan mendukung dalam perancangan database untuk mempermudah dan memperjelas dalam pengaksesan program yang akan dibuat. Peneliti mengumpulkan data mulai dari harga, merk, dan kategori kemudian menganalisa data tersebut agar sesuai dengan yang dibutuhkan..

2) System and software design

Peneliti menentukan dan membuat desain sistem dan aliran proses dari sistem yang akan dirancang.

3) Implementation and unit testing

Tahap ini merupakan pengkodean dari desain ke dalam suatu bahasa pemrograman. Peneliti mulai melakukan pengkodean menggunakan bahasa pemrograman Microsoft Visual Basic 6.0 untuk menciptakan desain sistem dan aliran proses yang telah dirancang sebelumnya.

4) Integration and system testing.

Peneliti melakukan testing pada aplikasi yang telah dibuat untuk menguji apakah sistem telah berjalan sesuai dengan yang diinginkan.

GO INFOTECH: JURNAL ILMIAH STMIK AUB Vol. 25, No. 2, Desember 2019: 82 - 96 
5) Operation and maintenance.

Pada tahap akhir ini, penulis melakukan perawatan mulai dari software dan hardware agar performa dari sistem yang telah dibuat tetap stabil.

\subsection{Metode Waterfall}

Tahapan-tahapan yang terdapat dalam metode waterfall dapat dilihat pada gambar 1 sebagai berikut:

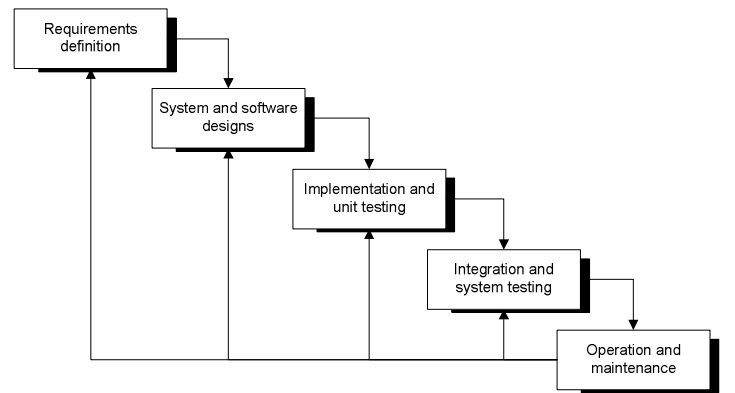

Gambar 1 Model Waterfall

a. Requirements analysis and définition adalah mengumpulkan kebutuhan secara lengkap kemudian dianalisa dan didefinisikan kebutuhan yang harus dipenuhi oleh program yang akan dibangun. Fase ini harus dikerjakan secara lengkap untuk bisa menghasilkan desain yang lengkap.

b. System and software design adalah desain dikerjakan setelah kebutuhan selesai dikumpulkan secara lengkap.

c. Implementation and unit testing adalah desain program diterjemahkan ke dalam kode-kode dengan menggunakan bahasa pemrograman yang sudah ditentukan program yang dibangun langsung diuji baik secara unit.

d. Intégration and system testing adalah penyatuan unit-unit program kemudian diuji secara keseluruhan (system testing).

e. Opération and maintenance adalah mengoperasikan program di lingkunganya dan melakukan pemeliharaan, seperti penyesuaian atau perubahan karena adaptasi dengan situasi sebenarnya. (Hanif, 2007)

2.3 Diagram Use Case

Diagram Use case memperlihatkan himpunan Use case dan aktor-aktor dan sangat penting untuk mengorganisasi dan memodelkan perilaku dari suatu sistem. Diagram Use case tampak pada gambar 2.

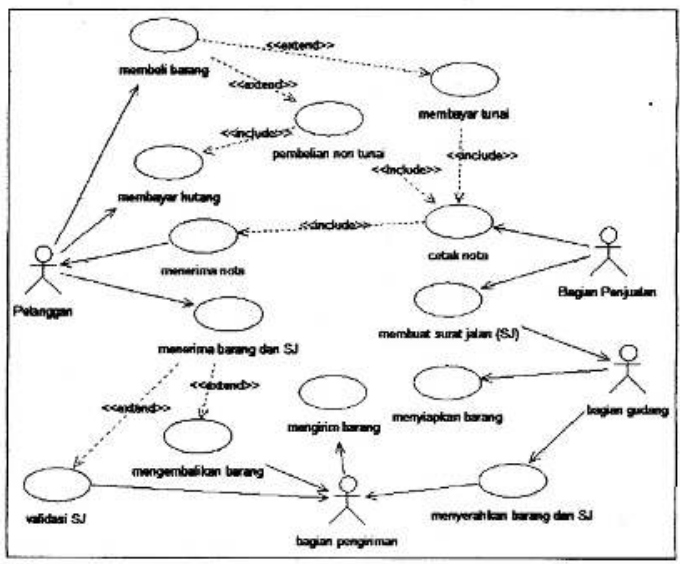

Gambar 2 Diagram Use case Penjualan Dan Pengiriman 


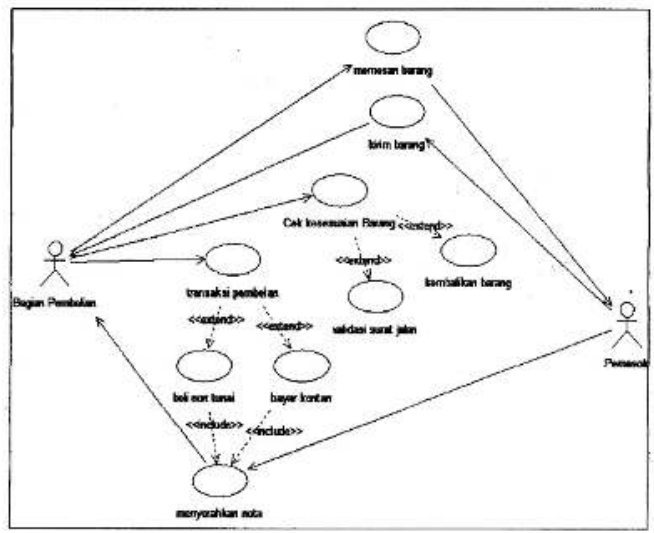

Gambar 2 Diagram Use case Pembelian

\subsection{Relasi Antar Tabel}

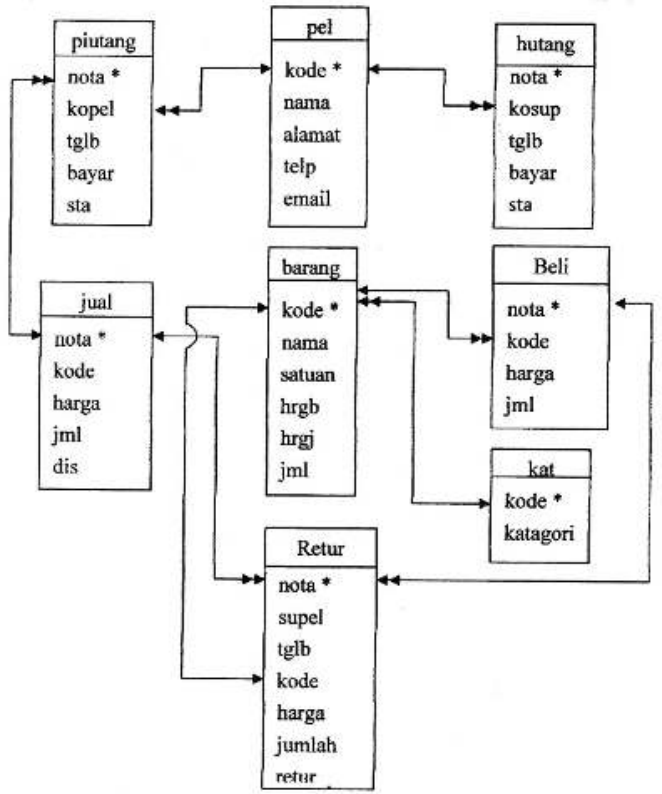

Keterangan :

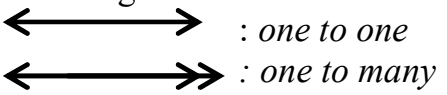

Gambar 3 Relasi Antar Tabel

\section{HASIL DAN PEMBAHASAN}

\subsection{Hasil Penelitian}

Implementasi sistem pada Sistem Informasi Penjualan Toko Besi dan Bangunan "Subur" Delanggu akan digambarkan dengan bagan alir sebagai berikut :

1. Login

Bagan alir login menggambarkan cara kerja dari proses login. Hanya admin yang dapat mengakses sistem. Bagan alir login dapat dilihat pada gambar 4. 
Bagan alir menu

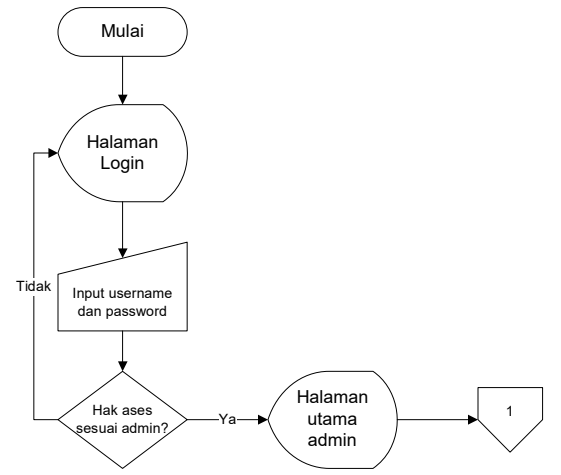

Gambar 4 Bagan alir login

Bagan alir menu halaman utama admin dapat dilihat pada gambar 5 sebagai berikut :

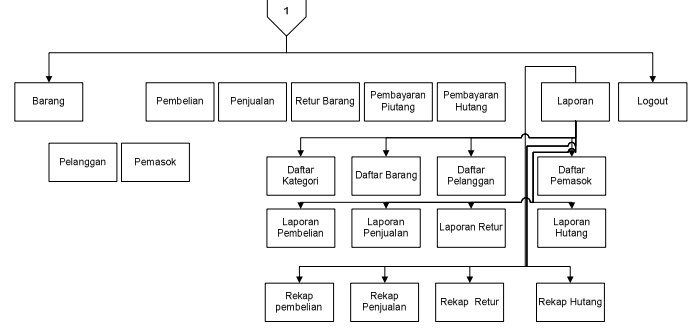

Gambar 5 Bagan Alir Menu Halaman Utama Admin

2. Bagan alir pengelolaan data master barang

Bagan alir pengelolaan data master barang menggambarkan alur proses kerja pengelolaan data master barang yang dilakukan oleh admin untuk input dan update data master barang. Bagan alir pengelolaan data master barang dapat dilihat pada gambar 6 .

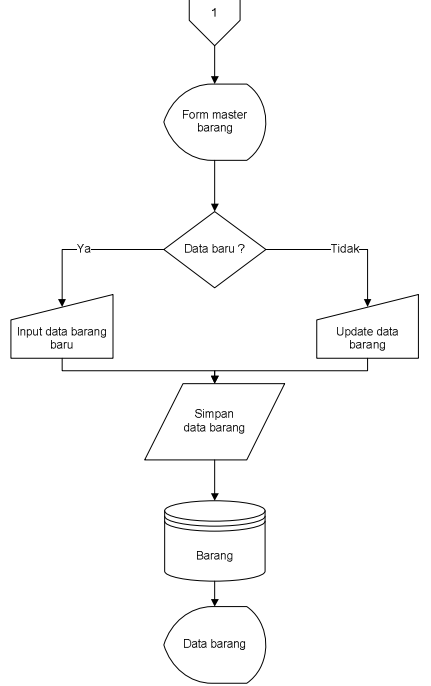

Gambar 6 Bagan alir pengelolaan data master barang

3. Bagan alir master data pelanggan dan pemasok

Bagan alir pengelolaan data master pelanggan dan pemasok menggambarkan alur proses kerja pengelolaan data master pelanggan dan pemasok yang dilakukan oleh admin untuk input dan update data master pelanggan dan pemasok. Bagan alir pengelolaan data master pelanggan dan pemasok dapat dilihat pada gambar 7 . 


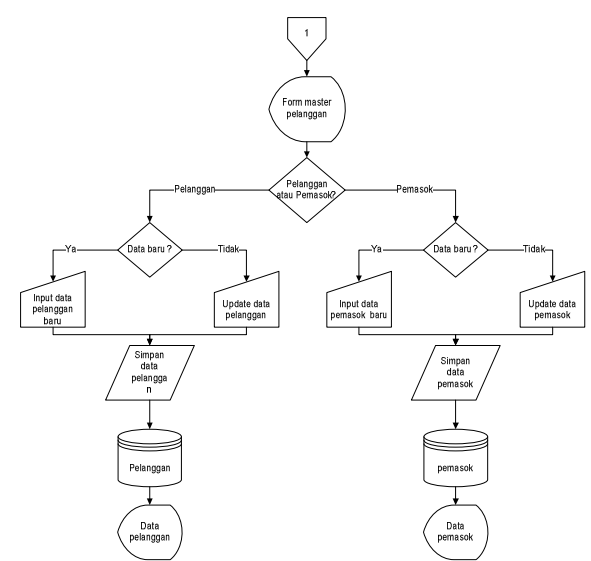

Gambar 7 Bagan alir pengelolaan data master pelanggan dan pemasok

4. Bagan alir pembelian barang

Bagan alir pembelian barang menggambarkan alur kerja dari proses pembelian barang yang dilakukan oleh admin. Bagan alir pembelian barang dapat dilihat pada gambar 8 .

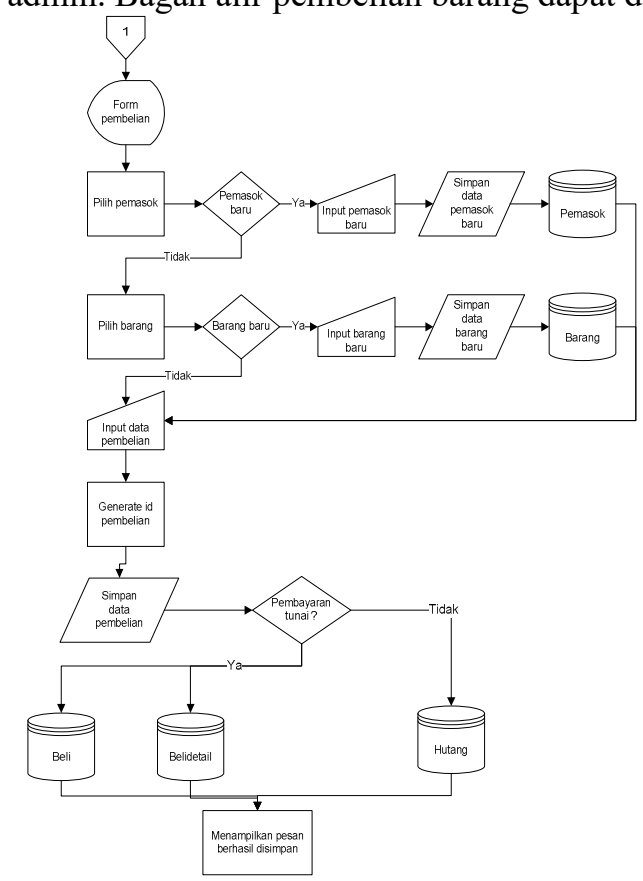

Gambar 8 Bagan alir pembelian barang

5. Bagan alir penjualan barang

Bagan alir pembelian barang menggambarkan alur kerja dari proses pembelian barang yang dilakukan oleh admin. Bagan alir pembelian barang dapat dilihat pada gambar 9 .

GO INFOTECH: JURNAL ILMIAH STMIK AUB Vol. 25, No. 2, Desember 2019: 82 - 96 


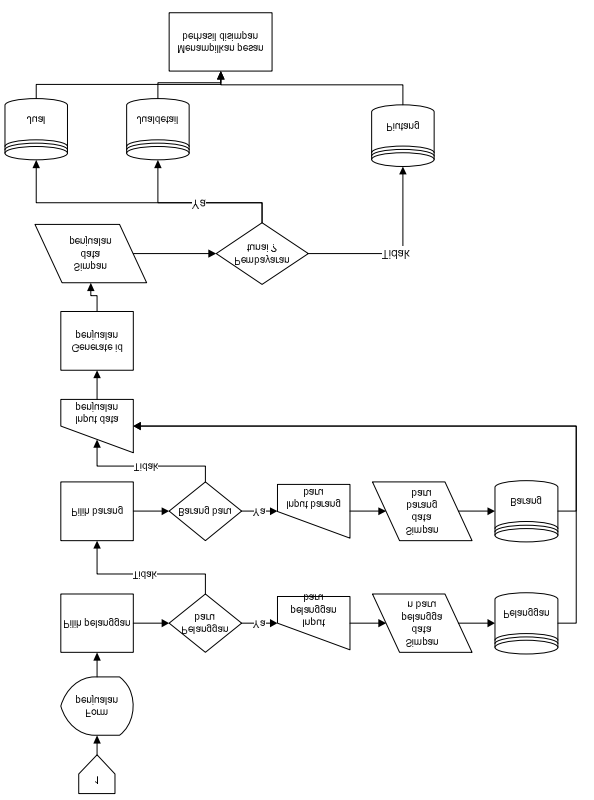

6. Bagan alir retur pembelian

Gambar 9 Bagan alir penjualan barang

Bagan alir retur pembelian barang menggambarkan alur kerja dari proses retur pembelian barang yang dilakukan oleh admin. Bagan alir retur pembelian barang dapat dilihat pada Gambar 10.

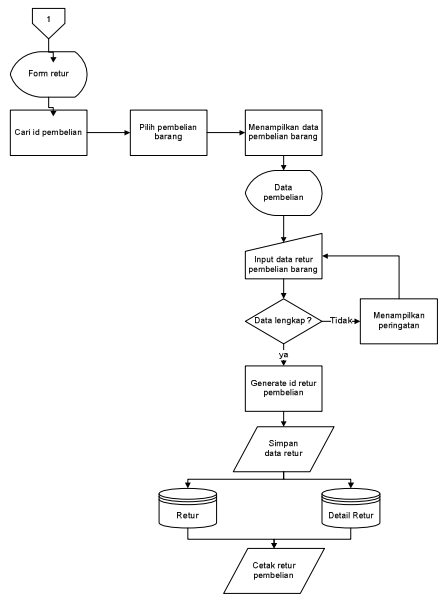

Gambar 10 Bagan alir retur pembelian barang

7. Bagan alir pembayaran piutang

Bagan alir pembayaran piutang menggambarkan alur kerja dari proses pembayaran piutang yang dilakukan oleh admin. Bagan alir pembayaran piutang dapat dilihat pada gambar 11 . 


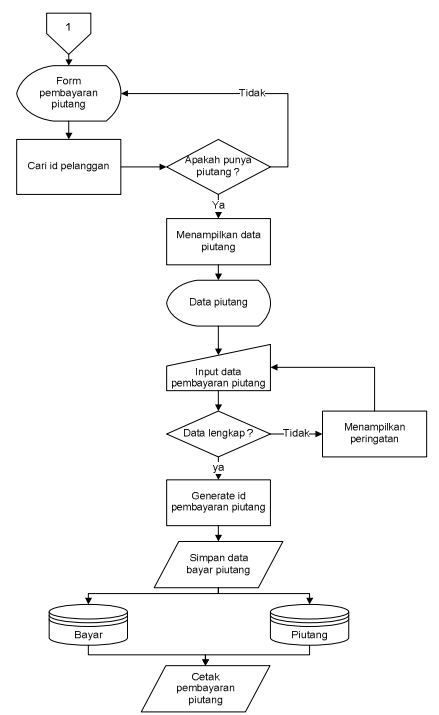

Gambar 11 bagan alir pembayaran piutang

8. Bagan alir pembayaran hutang

Bagan alir pembayaran hutang menggambarkan alur kerja dari proses pembayaran hutang yang dilakukan oleh admin. Bagan alir pembayaran hutang dapat dilihat pada gambar 12 .

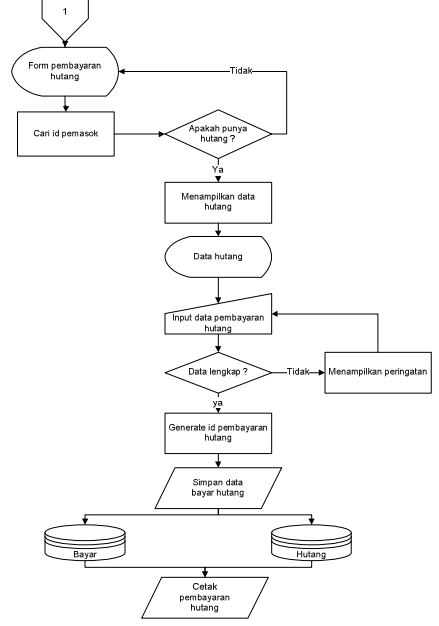

9. Bagan alir pembuatan laporan

Gambar 12 bagan alir pembayaran hutang

Bagan alir pembuatan laporan menggambarkan alur proses kerja pembuatan laporan yang dapat diakses oleh admin. Admin berwenang melihat dan mencetak laporan keuangan sesuai dengan periode waktu yang diinginkan.

GO INFOTECH: JURNAL ILMIAH STMIK AUB Vol. 25, No. 2, Desember 2019: 82 - 96 


\subsection{Pembahasan}

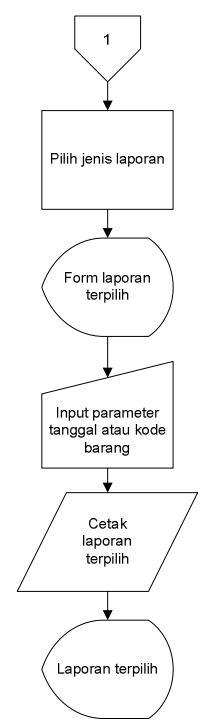

Gambar 13 Bagan alir pembuatan laporan

Langkah pertama dalam menggunakan aplikasi dalam penelitian ini adalah memanggil file executable (.exe) yang sudah dijadikan shortcut pada halaman utama windows bernama subur maka akan tampil seperti gambar 14.

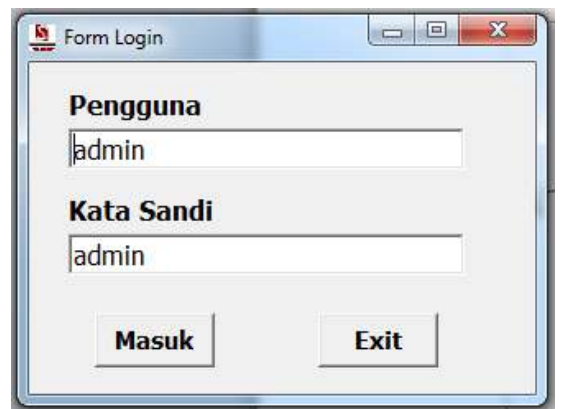

1. Tampilan Menu

Gambar 14 Tampilan login

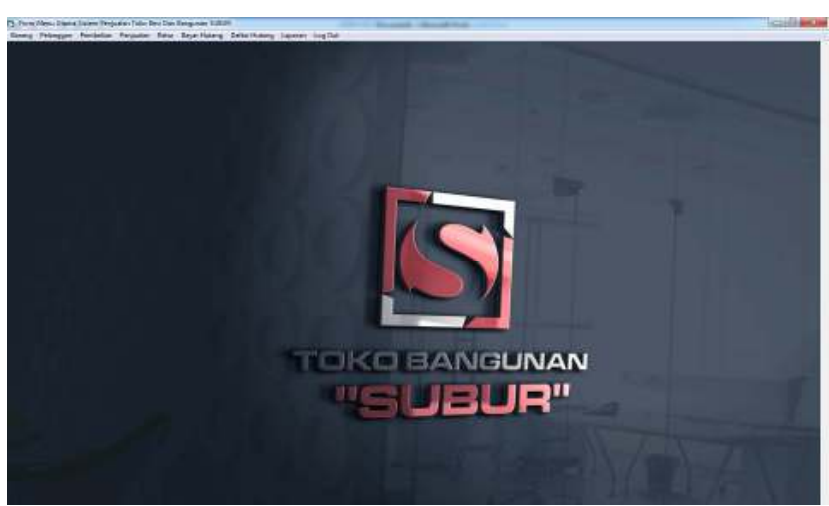

Gambar 15 Tampilan Menu Utama

Untuk menjalankan menu, misal ingin memilih menu pengolah barang maka klik menu barang atau Alt + B untuk memilih menu Barang, maka akan muncul form untuk pengolahan data barang, untuk memilih menu yang lain bisa dilakukan dengan menekan keyboard arah ke kanan, ke kiri atau apabila ada submenu tekan keyboard ke bawah atau ke atas.

2. Pengolahan Data Barang 


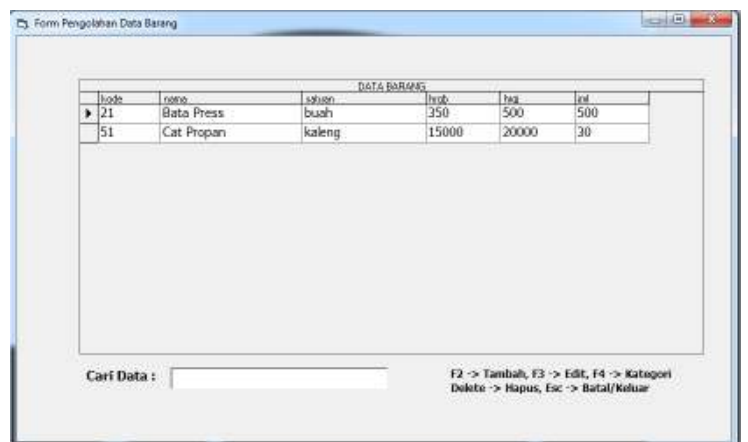

Gambar 16 Tampilan Pengolahan Data Barang

Setelah melakukan pencarian, jika ingin merubah data maka pengguna harus menekan tombol edit terlebih dahulu baru dapat merubah data yang ada di tabel. Perubahan data dapat dilakukan langsung di tabel dengan merubah data yang dimaksud. Ketika pengguna ingin menghapus data, pertama kali harus memilih data yang akan dihapus dengan cara klik data yang ada di tabel sesuai dengan yang akan dihapus lalu tekan tombol hapus maka akan muncul konfirmasi untuk meyakinkan penghapusan.

3. Pengolahan Data Pelanggan Atau Pemasok

Untuk efisiensi program maka pengolahan data pelanggan dan pemasok dijadikan dalam satu form seperti tampak pada gambar 4.9 dan 4.10. Kode digunakan untuk membedakan antara pelanggan dan pemasok, jika karakter pertama adalah "C" maka data tersebut adalah milik pelanggan, jika "S" maka data pemasok. Cara pengoperasian pengolahan data pelanggan atau pemasok sama dengan proses pengolahan data barang. Dalam pengolahann ini juga terdapat tambah data, pencarian data, merubah dan menghapus data. Jika ingin menambah data maka pengguna harus memilih jenis terlebih dahulu yaitu pelanggan atau pemasok.

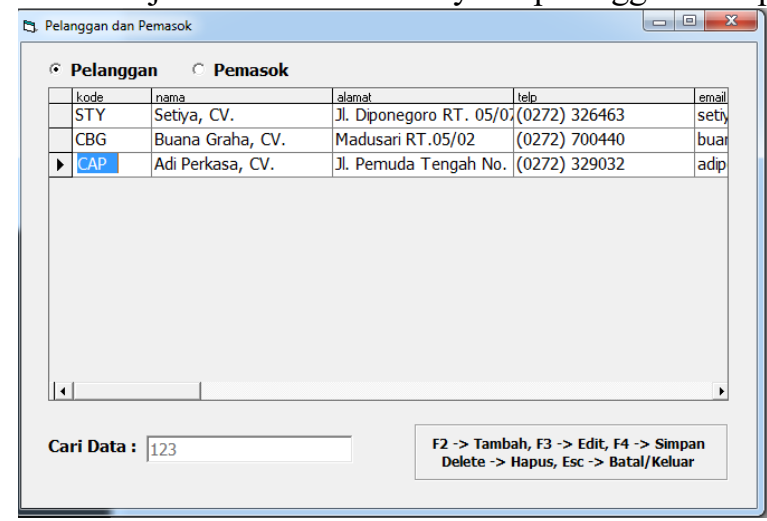

Gambar 17 Tampilan Pengolahan Data Pelanggan dan Pemasok

Untuk menjalankan data pelanggan, klik pada option button pelanggan, selanjutnya untuk menambah data pelanggan tekan F2, untuk mengedit data pelanggan double klik pada grid, kemudian tekan F3 dan lakukan simpan untuk mengupdate data yang diedit, apabila ingin menghapus data pelanggan maka double klik pada data grid yang ditandai, kemudian tekan delete dan tekan esc untuk keluar dari form pelanggan. 


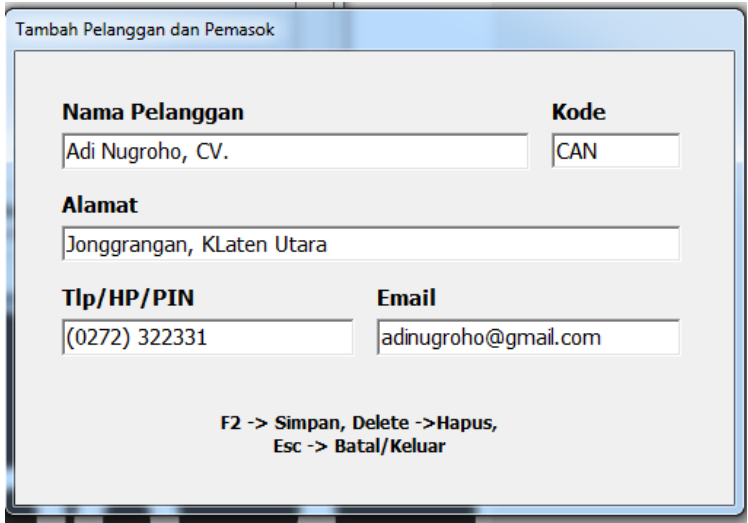

4. Pengolahan Transaksi Pembelian

Gambar 18 Tampilan Input Data Pelanggan dan Pemasok

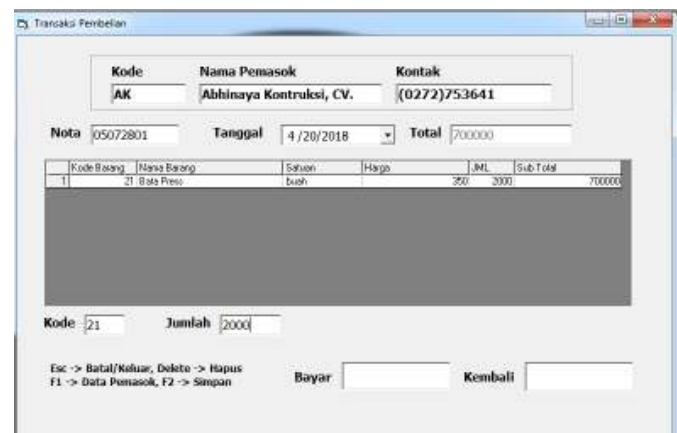

Gambar 19 Tampilan Transaksi Pembelian

Untuk mengoperasikan transaksi pembelian, pertama kali pengguna harus memasukkan kode pemasok. Tombol F1 berfungsi untuk menampilkan form pencarian pemasok yang tampilannya sama dengan gambar 4.18 , hal ini dilakukan jika pengguna tid? hapal kode pemasok. Setelah memilih pemasok maka kode, nama dan kontak akan muncul otomatis. Nota diisi dengan nomor nota atau faktur yang berasal dari pemasok. Tanggal sudah muncul otomatis sesuai dengan tanggal sistem komputer yang digunakan.

5. Pengolahan Transaksi Penjualan

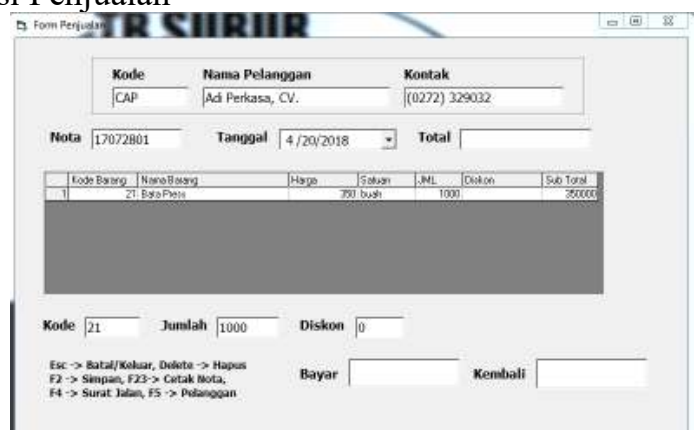

Gambar 20 Tampilan Transaksi Penjualan

Untuk melakukan transaksi penjualan, pertama kali harus memasukkan kode pelanggan, jika kode tersebut ada maka nama pelanggan dan kontak akan muncul otomatis. Nomor nota muncul otomatis sesuai format yang ditentukan. Tanggal transaksi diambil dari tanggal sistem komputer yang digunakan. Langkah selanjutnya adalah memasukkan data barang yang dijual di dalam tabel transaksi yang telah disediakan. Pengguna memasukkan kode barang pada kolom pertama, jika ketemu maka nama, harga dan satuan akan muncul otomatis di kolom sebelah kanannya. Kursor akan otomatis menuju pada kolom jumlah, pengguna diminta memasukkan jumlah barang yang dibeli pelanggan. Selanjutnya pengguna diminta memasukkan diskon, nilai 
awal diskon adalah nol. Diskon dapat dimasukkan dalam satuan persen maupun rupiah, jika pengguna memasukkan diskon lebih kecil atau sama dengan 100 maka dianggap persen, jika lebih besar 100 maka dianggap rupiah. Setalah memasukkan diskon maka sub total muncul otomatis yang didapat dari perhitungan jumlah dikalikan harga dikurangi diskon.

6. Pengolahan Transaksi Pembayaran Piutang

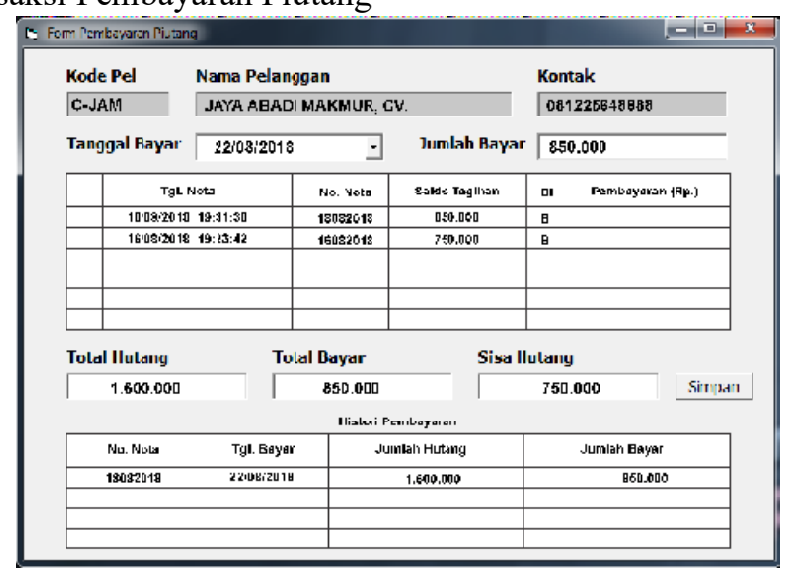

Gambar 21 Tampilan Transaksi Pembayaran Piutang

Dalam proses transaksi pembayaran piutang atau pembayaran hutang pelanggan, pengguna harus memasukkan kode pelanggan terlebih dahulu, jika kode tersebut ada maka nama dan kontak pelanggan muncul otomatis. Selain menampilkan data pelanggan, sistem juga menampilkan data hutang dari pelanggan tersebut di dalam tabel yang tersedia dan menampilkan pembayaran yang pernah dilakukan pada tabel yang berada di bawah.

7. Cetak Laporan

Terdapat tiga jenis output yang dihasilkan yaitu daftar, laporan dan rekap. Untuk mencetak laporan pembelian, pengguna dapat mencetak laporan transaksi untuk seorang pemasok atau semua juga dapat melakukan pencetakan per periode tanggal. Agar dapat mencetak laporan atau rekap per pelanggan maupun pemasok, pengguna harus mengisi kode pelanggan atau pemasok terlebih dahulu. Jika kode dikosongkan maka yang dicetak adalah transaksi semua pemasok atau pelanggan. Pengguna juga dapat mencetak transaksi per periode tanggal sehingga dapat lebih fleksibel jika ingin mencetak laporan harian atau mingguan, bulanan bahkan tahunan. Tampilan form mencetak laporan tampak pada gambar 22 .

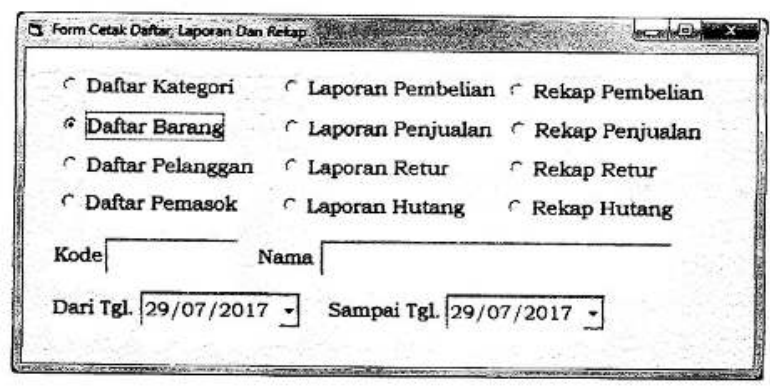

Gambar 22 Tampilan Laporan

Berikut beberapa output laporan-laporan yang digunakan Toko Besi dan Bangunan "Subur" :

GO INFOTECH: JURNAL ILMIAH STMIK AUB Vol. 25, No. 2, Desember 2019: 82 - 96 
1) Daftar Pelanggan

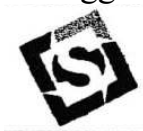

Toko Besi Dan Bangunan

Jl. Klaten-Solo, Delanggu SU BUT

\begin{tabular}{llll}
\hline & & DAFTAR PELANGGAN & \\
Kode & Nama pelanggan & Alamat & No. Telpon \\
\hline STY & Setiya, CV. & Jl. Diponegoro RT. 05/07 Klaten & (0272) 326463 \\
CBG & Buana Graha, CV. & Madusari RT.05/02 & (0272) 700440 \\
CAP & Adi Perkasa, CV. & Jl. Pemuda Tengah No. 116 & (0272) 329032 \\
CAN & Adi Nugroho, CV. & Jonggrangan, KLaten Utara & (0272) 322331 \\
& \multicolumn{2}{c}{ Gambar 23 Output Laporan Daftar Pelanggan } &
\end{tabular}

2) Daftar Pemasok Gambar 23 Output Laporan Daftar Pelanggan

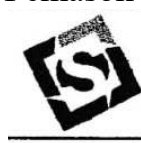

Toko Besi Dan Bangunan

Jl. Klaten-Solo, Delanggu

SUBUR

DAFTAR PEMASOK

\begin{tabular}{llll} 
Kode & Nama Pemasok & Alamat & No. Telpon \\
\hline AK & Abhinaya Kontruksi, CV. & Gemblegan RT. 01/08 Kalikotes & $(0272) 753641$ \\
AM & Aria Mandala, CV. Jl. Klaten - Solo Km. 27 & (0272) 423541
\end{tabular}

Gambar 24 Output Laporan Daftar Pemasok

3) Laporan Penjualan

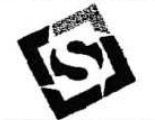

Toko Besi Dan Bangunan

Jl. Klaten-Solo, Delanggu SUDUTR

\begin{tabular}{|c|c|c|c|c|c|c|c|}
\hline \multirow[b]{2}{*}{ Nota } & \multicolumn{7}{|c|}{$\begin{array}{l}\text { LAPORAN PENJUALAN } \\
05 / 05 / 2018 \text { sd 05/05/2018 }\end{array}$} \\
\hline & Pelanggan & Barang & Satuan & Jumlah & Harga & Diskon & Subtotal \\
\hline 2326 & Setiya, CV. & $\begin{array}{l}\text { Cat Propan } \\
\text { nbar } 25 \mathrm{Ou}\end{array}$ & $\begin{array}{l}\text { Kaleng } \\
\text { ut Lapo }\end{array}$ & $\begin{array}{l}2 \\
\text { Penjual }\end{array}$ & 15.000 & - & 30.000 \\
\hline
\end{tabular}

4) Laporan Pembelian

$$
\text { Gambar } 25 \text { Output Laporan Penjualan }
$$

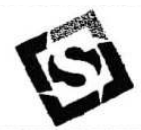

Toko Besi Dan Bangunan

Jl. Klaten-Solo, Delanggu

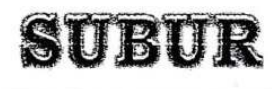

LAPORAN PEMBELIAN

05/05/2018 sd 05/05/2018

\begin{tabular}{|c|c|c|c|c|c|c|c|}
\hline Nota & Pemasok & Barang & Satuan & Jumlah & Harga & Diskon & Subtotal \\
\hline$\overline{0507}$ & 1 Aria Mandala & Bata Press & Buah & 500 & 350 & - & 175.000 \\
\hline
\end{tabular}

\section{KESIMPULAN}

Pencatatan akuntansi penjualan pada Toko Besi dan Bangunan "Subur" masih dilakukan secara manual, sehingga terjadi keterlambatan dalam penyampaian informasi mengenai data penjualan. Sistem informasi penjualan yang terkomputerisasi dengan aplikasi Microsoft Visual Basic 6.0 memiliki kelebihan dalam pengelolaan data penjualan, data 
pembelian, data pembayaran hutang dan pelaporan sehingga dapat dilakukan lebih mudah, cepat dan akurat.

\section{SARAN}

Sistem yang dibuat dalam penelitian ini masih menggunakan pemrograman desktop, untuk pengembangan lebih lanjut dapat dibuat dengan menggunakan pemrograman berbasis web atau bahasa pemrograman yang tidak berbayar.

\section{DAFTAR PUSTAKA}

[1] Fajrillah, Hasballah. 2009. Aplikasi Game dan Multi Media Dengan Visual Basic. PT Elex Media Komputindo. Jakarta

[2] Hanif, Al Fatta. 2007. Analisis dan Perancangan Sistem Informasi. Andi. Yogyakarta.Husen, Sadam. 2015. Rancang Bangun Sistem Informasi Manajemen Stok Barang Berbasis Web Toko Besi Bangunan Barokah Material Menggunakan Metode Eoq (Economic Order Quantity). Universitas Jember. Jember.

[3] Iswanti, 2014. Sistem Informasi Penjualan Pada Toko Besi Dan Bangunan Haji Kuat Kebumen. STMIK Amikom. Yogyakarta.

[4] Jayanto, 2005. Membuat Database Dengan Visual Basic, PT. Elexmedia Komputindo, Jakarta.

[5] Jogiyanto, HM. 2005. Analisis dan Disain Sistem Informatika; Pendekatan Terstuktur Teori dan Praktek Aplikasi Bisnis. Andi. Yogyakarta.

[6] Marom, Chairul. 2002, Sistem Akuntansi Perusahaan Dagang, Edisi ke-dua, Grasindo. Jakarta.

[7] Mulyadi. 2002. Auditing. Buku Dua. Edisi Ke Enam. Salemba Empat. Jakarta

[8] Mulyadi. 2008. Sistem Akuntansi. Salemba Empat. Jakarta

[9] Munawir. 2004. Analisis Laporan Keuangan. Edisi Ke-4. Liberty. Yogyakarta

[10] Nawawi, Hadari. 2005. Penelitian Terapan. Gajah Mada University Press. Yogyakarta.

[11] Nizar, Muhammad Rofiq. 2015 Perancangan Sistem Penjualan Berbasis Web Pada Toko Besi Setia Madiun. Universitas Muhammadiyah Ponorogo. Ponorogo.

[12] Simamora, Henry. 2002. Akuntansi : Basis Pengambilan Keputusan Bisnis. Jakarta: Salemba Empat.

[13] Solihin, Achmad. 2014. MySQL Dari Pemula Hingga Mahir. Universitas Budi Luhur. Jakarta

[14] Sugiyono. 2013, Metodelogi Penelitian Kuantitatif, Kualitatif Dan R\&D. Bandung: Alfabeta.

[15] Widodo, Prabowo Pudjo dan Herlawati. 2011. Menggunakan UML. Informatika. Jakarta.

GO INFOTECH: JURNAL ILMIAH STMIK AUB Vol. 25, No. 2, Desember 2019: 82 - 96 